\section{Overblown claims}

\author{
Martin Kohlmeier
}

\section{BURDEN OF PROOF}

When I am thinking about overblown nutrition claims, various extravagant theories and hyped nostrums readily come to mind. What makes them stand out as easy targets for criticism and disdain is their obvious lack of credible evidence. Taking them down almost seems unfair because it is just so easy. The same cannot be said about some claims attempting to refute well-established nutrition knowledge by pointing to purported weaknesses of the supporting evidence. However, there cannot be any doubt that the burden of proof still rests with the ones claiming that current science got it wrong. And even if that criticism was justified, we have to remember that invalidating a conventional position does not lead by default to a particular opposing conclusion because there are usually various possible alternatives. Biology is rarely black and white with clearly defined polar opposites. As importantly, common kinds of biases make it very unlikely that a new claim challenging conventional science will hold up over the long run. ${ }^{1}$ This high rate of ultimately unsubstantiated claims is caused, among other reasons, by publication bias, which describes the tendency to favour the reporting, publishing and citing of controversial claims going against prevailing science, and thereby giving them outsized weight and visibility. It often takes many years until more confirmations of established science eventually bring the pendulum of public opinion back again to the original evidence-based position. Good science is a rough and tumble process that depends on questioning the status quo, but questioning comes with significant responsibility. Proponents wishing to challenge an established scientific viewpoint have to

Correspondence to Dr Martin Kohlmeier, School of Medicine, Gillings School of Global Public Health, and UNC Nutrition Research Institute, University of North Carolina at Chapel Hill, Kannapolis, North Carolina 28081, USA; MKOHLMEIER@UNC.EDU do all the hard work and build a credible case for their opposing claim. This is not easy, and it should not be easy, because many different kinds of experiences and experiments have built the current state of knowledge. Passionately held beliefs about good nutrition are of little use without stronger evidence support for them than for the currently prevailing views, complaints about suppressed freedom of speech and conspiracies involving commercial interests notwithstanding. That said, it is in the interest of the scientific community to make every effort to continue explaining how evidence supports current recommendations and present these considerations in an accessible format to healthcare providers. It is also the responsibility of funding agencies to support research that can fill identified gaps in the science and strengthen the evidence base.

\section{UPDATING NUTRITION SCIENCE}

Even more extreme claims state that conventional nutrition science is fatally flawed in general, often pointing to past flips of mainstream positions. How many times have we heard that nutrition recommendations have moved from demonising egg consumption to accepting that having one or more eggs per day is not a health risk? Among the reasons why the risk of egg consumption needed to be reassessed is the very close correlation of cholesterol and the essential nutrient choline in foods. When we avoid cholesterol-rich foods, our supply of dietary choline almost invariably goes down as well with potentially harmful consequences. ${ }^{2}$ Previously, the importance of choline was not well understood, and we now have to take this into account when considering good food choices. Many mistake changes of nutrition recommendations as a sign of weak science when it is very much the opposite, demonstrating the ability to adjust scientific positions in response to evolving evidence. If our world views had not embraced the rapidly growing stream of new findings and insights during the recent centuries and decades, we would still not be able to prevent scurvy by ensuring adequate vitamin C intake. A concise review of case reports finding scurvy in at-risk alcoholics in this Journal ${ }^{\beta}$ reminds us of the practical importance of such seemingly obvious, but still important science facts. Previously presented overblown claims of benefits from megadose vitamin C supplementation for everybody should not obscure the fact that dangerous nutrition deficiencies are still with us, particularly in at-risk individuals and food-insecure populations.

\section{STRENGTHENING CREDIBILITY}

If we learn that a previously held assumption is mistaken, we have to be clear about why we are adopting an alternative view, and we should proactively explain the new rationale to those we care for and the public. There is no neutral position about most foods and their constituent nutrients that we necessarily consume every day. Either our intake is in the right range or it is not. We may not be able to figure out the right answer now or later, but sitting on the fence is not a safe default option. To see the continuous evolution of our nutrition knowledge as a sign of faulty science turns good practice on its head. It cannot be emphasised enough that credible science has to change if warranted by the analysis of all available evidence and understanding. One of the major differences between science and pseudoscience is that even the most entrenched tenets of nutrition science are not sacrosanct and must be held up to perpetual scrutiny. However, challengers claiming refutation of current science have no personal entitlement to examination and change at a given time, not least because there is no official court of appeal. It falls to the challengers to convince the scientific community with strong new evidence and conclusive demonstration of a better predictive model. Until that has been achieved, the conventional views necessarily must prevail. An important motivation driving such a conservative view of dealing with claims refuting established nutrition principles is that the negation of effective nutrition practices, guidelines and recommendations comes with 
a significant cost. The well-being and even the lives of millions of people are at stake, limited resources may be misdirected, and the trust of the public in the quality of nutrition science could be undermined. There is enough evidence to confidently expect that more than half of all diseases and causes of premature death involve improper care and feeding of our bodies. ${ }^{4-7}$ If we get it wrong, the consequences are likely to be substantial and that is why we must care about using the best science.

\section{DECISION SUPPORT FOR PRACTITIONERS}

To help clinicians and other healthcare providers navigate the often contradictory and confusing voices on effective nutrition assessment and intervention practices, BMJ Nutrition, Prevention \& Health will present a series of concise answers to important nutrition questions. The first of these vignettes has now been compiled by Kris-Etherton and colleagues ${ }^{8}$ concerning the current state of evidence about the known harms from high intake of palmitate and other blood cholesterol-raising saturated fats. They illustrate that the currently available evidence strongly supports that people with high consumption of such saturated fats have an increased risk of cardiovascular disease. This high risk can be reduced when some of the saturated fat is replaced by unsaturated fats, but not by replacing it with sugars or other carbohydrates. While it continues to be very difficult to change entrenched habits, at least the direction of the desirable change towards lowering saturated fat consumption has been clear for a while.

Funding The authors have not declared a specific grant for this research from any funding agency in the public, commercial or not-for-profit sectors.

Competing interests None declared.

Patient consent Not required.

Provenance and peer review Commissioned; internally peer reviewed.

\section{0 OPEN ACCESS}

Open Access This is an open access article distributed in accordance with the Creative Commons Attribution Non Commercial (CC BY-NC 4.0) license, which permits others to distribute, remix, adapt, build upon this work non-commercially, and license their derivative works on different terms, provided the original work is properly cited, appropriate credit is given, any changes made indicated, and the use is non-commercial. See: http://creativecommons.org/ licenses/by-nc/4.0

(C) Author(s) (or their employer(s)) 2018. Re-use permitted under CC BY-NC. No commercial re-use. See rights and permissions. Published by BMJ.

\section{Check for updates}

To cite Kohlmeier M. bmjnph 2018;1:5-6.
Received 20 November 2018

Accepted 20 November 2018

Published Online First 10 December 2018

bmjnph 2018;1:5-6.

doi:10.1136/bmjnph-2018-000015

\section{REFERENCES}

1. Ioannidis JP. Why most published research findings are false. PLoS Med 2005;2:e124.

2. Kohlmeier M, da Costa KA, Fischer LM, et al. Genetic variation of folate-mediated one-carbon transfer pathway predicts susceptibility to choline deficiency in humans. Proc Natl Acad Sci U S A 2005;102:16025-30.

3. Lim DJ, Sharma Y, Thompson CH. Vitamin C and alcohol: aA call to action. BMJ Nutr Prev Health 2018;1:16-21.

4. Lai JS, Hiles S, Bisquera A, et al. A systematic review and meta-analysis of dietary patterns and depression in community-dwelling adults. Am J Clin Nutr 2014;99:181-97.

5. Lim SS, Vos T, Flaxman AD, et al. A comparative risk assessment of burden of disease and injury attributable to 67 risk factors and risk factor clusters in 21 regions, 1990-2010: a systematic analysis for the Global Burden of Disease Study 2010. Lancet 2012;380:2224-60.

6. Ministry of Health and the University of Auckland. Nutrition and the burden of disease: New Zealand 1997-2011. Wellington: Ministry of Health, 2003.

7. Melaku YA, Renzaho A, Gill TK, et al. Burden and trend of diet-related noncommunicable diseases in Australia and comparison with 34 OECD countries, 19902015: findings from the Global Burden of Disease Study 2015. Eur J Nutr 2018;2015.

8. Kris-Etherton P, Petersen K, Van Horn L. Convincing evidence supports reducing saturated fat to decrease cardiovascular disease risk. BMJ Nutr Prev Health 2018;1:22-5. 